\title{
Indonesian Adolescents' Online Opportunities and Risks
}

\author{
Amia Luthfia ${ }^{1}$, Pinckey Triputra $^{2}$, Hendriyani $^{3}$ \\ ${ }^{1}$ Marketing Communication Program, Communication Department, \\ Faculty of Economics \& Communication, Bina Nusantara University, \\ Jl. Kh. Syahdan No. 9, Kemanggisan, Palmerah, Jakarta 11480, Indonesia \\ ${ }^{2,3}$ Communication Department, \\ Faculty of Social and Political Science, University of Indonesia, \\ Kampus UI Depok, Depok 16424, Indonesia \\ amialuthfia@binus.ac.id/amialuthfia@gmail.com
}

\begin{abstract}
This research aims to 1) explore the benefits of online (benefits obtained when on the internet) and online risks (risks experienced when on the internet) in adolescents in Jakarta; 2) Test differences in online benefits and online risk based on differences in gender, education level, and school affiliation. This study used a survey method with a multilevel random sampling technique performed on adolescents living in Jakarta aged 12-18 ( $N$ = 756). The data analysis technique for this study is descriptive analysis and T-test analysis. The results of the research show that teenagers in Jakarta regularly use the internet every day with relatively high duration. More than $60 \%$ of teens benefit online in the medium to the high category, with six types of benefits online: learning, creative participation, social participation, social relations, entertainment, commercial benefits, and personal benefits. Most teens experience online risk in the low category, with three types of risks: content risk, contact risk, and behavioral risk. Other findings, namely: (1) there are significant differences in online risk-based on sex and adolescent education level; (2) significant differences in online benefits are based solely on adolescent education levels. There are no significant differences in online and online risk benefits based on school affiliation (non-religious schools and religion-based schools). This research contributes to the importance of distinguishing online benefits and online risks from adolescent education levels.
\end{abstract}

Keywords: Adolescents, Internet Use, Online Benefits, Online Risk

\begin{abstract}
Abstrak
Penelitian ini bertujuan untuk 1) mengeksplorasi manfaat daring (manfaat yang diperoleh ketika dalam jaringan internet) dan risiko daring (risiko yang dialami ketika dalam jaringan internet) pada remaja di Jakarta; 2) Menguji perbedaan manfaat daring dan risiko daring berdasarkan perbedaan gender, tingkat pendidikan, dan afiliasi sekolah. Penelitian ini menggunakan metode survei dengan teknik sampel acak bertingkat yang dilakukan pada remaja yang tinggal di Jakarta usia 12-18 ( $\mathrm{N}=$ 756). Teknik analisis data untuk penelitian ini adalah analisis deskriptif dan analisis T-test. Hasil penelitian menunjukkan bahwa remaja di Jakarta secara teratur menggunakan internet setiap hari dengan durasi yang relatif tinggi. Lebih dari $60 \%$ remaja memperoleh manfaat daring dalam kategori sedang hingga tinggi, dengan enam jenis manfaat daring: pembelajaran, partisipasi kreatif, partisipasi sosial, hubungan sosial, hiburan, keuntungan komersial, dan keuntungan pribadi. Sebagian besar remaja mengalami risiko daring dalam kategori rendah, dengan tiga jenis risiko: risiko konten, risiko kontak, dan risiko perilaku. Temuan lain, yaitu: (1) terdapat perbedaan signifikan pada risiko daring berdasarkan jenis kelamin dan tingkat pendidikan remaja; (2) perbedaan signifikan pada manfaat daring hanya berdasarkan tingkat pendidikan remaja. Tidak ada perbedaan signifikan dalam manfaat daring dan risiko daring berdasarkan afiliasi sekolah (sekolah non-agama dan sekolah berbasis agama). Penelitian ini memberikan kontribusi pentingnya membedakan manfaat daring dan risiko daring dari tingkat pendidikan remaja.
\end{abstract}

Kata kunci: Remaja, Penggunaan Internet, Manfaat Daring, Risiko Daring 


\section{Introduction}

The internet is a communication technology that has the capacity as an interpersonal medium as well as a mass medium and shows the connection between interpersonal communication and mass communication (Borah, 2017). Personal media like smartphones has disrupted the boundaries between mass communication and interpersonal communication (Rice, 2017). As a result, the existence of the internet and digital technology provides a new experience for its users because media now involve multiple, multitasking, interdependent, layered, and blended media (Rice, 2017).

Now, adolescents internet users in Indonesia have reached 23.89 million people (APJII, 2017). Internet and other communication technologies have become a part of today's teenage life. Adolescents are the most active users of communication technology as well as the group with the most potential to use the internet which they consider having attractive characteristics and capacity.

Since adolescents are active users of the internet medium, the relevant theory to explore youth internet activities is the Uses and Gratifications Theory (U\&G) because this theory considers internet user actively determine media and content based on their motives. U\&G is a cutting-edge theory of each new mass communication medium, and now the internet (Ruggiero, 2016). With the large number of social media usage among adolescents, U\&G seems regain communication scholars' interest, as it can provide insights of what motives and what people do to media (Quan-Hasse \& Young, 2014). Another consideration for using the Uses \& Gratifications Theory, there is an aspect within this theory that got less attention from $U \& G$ researchers, i.e. aspects of consequences.

How about the consequences resulting from internet usage? Most studies of internet usage were still focused on the study of motives and gratifications (Sundar \& Limperos, 2013). The study that specifically examines internet consequences were still limited. One of consequences research that has been studied with U\&G perspective was internet addiction and social media addiction (Baek, Cho, \& Kim, 2014; Chin Hooi, 2011; Leung, 2008, 2014). This study examines other consequences that are not addiction. Then, to study further about the consequences of internet usage, this research refers to Livingstone's research. Livingstone used the concept of online opportunity for intended consequences and the concept of online risk for unintended consequences.

Online opportunity regarded as a "new participation" for adolescents where they can express themselves, to socialize, get involved in the community, creating, acquiring knowledge and new competencies (Livingstone, 2008), even including the opportunity to perform a risky behavior (Livingstone \& Haddon, 2014). In addition, digital technology is increasingly enabling children and adolescents to create and content that makes them involved in a creative production. This participation was stated in several terms: online opportunity 
(Livingstone, Bober, \& Helsper, 2005); participatory culture (Jenkins, 2006) and "hyper sociality" (Ito, 2007; Ito et al., 2009).

Online risk concept defined as various experience intentionally or unintentionally deliberately experienced by internet users that lead to unintended consequences, negative or harmful, and can damage values, physical, and mental health (Livingstone, 2011; Livingstone \& Helsper, 2010; Livingstone, Mascheroni, \& Staksrud, 2015; Staksrud \& Livingstone, 2009).

Adolescents in this era love to try new things that offer new experiences and sensations, they rapidly absorb new technology and process visual information, multitasker, and imaginative. Nevertheless they are vulnerable to the negative impact of the internet that make them more impulsive, more aggressive, and earlier "mature" (Livingstone, 2011; Steiner-Adair \& Barker, 2013). Adolescents has their own motives and needs for accessing the internet, determine channels \& content, produce content and where/to whom content is distributed. Different motives and needs can offer its own consequences, whether positive or negative consequences. Then, it is necessary to anticipate all the consequences of internet use by adolescents. Moreover, adolescents are very interested in new technology and have a high curiosity of it.

There were many news about the adolescents and children become victims or actor of their activities on the internet such as cyberbullying, pornography addiction, sexting or pornography content sharing, pedophilia victim, etc. (Kompas, 2018b, 2018a; Michelle \& Ramadan, 2018). A case as the effect of internet negative exposure was an online survey conducted by Haionline magazine on 102 teenage boys and 148 teenage girls aged 17-20 years. Fifty nine male teens had sent nude photos with their girlfriends, 31 teenagers had spread nude photos and 41 teenagers had a group chat to share nude photos (Michelle \& Ramadan, 2018).

Actually, adolescents also get a lot of benefits from the internet such as creating something, learning various things, interact with friends and family, participate in social activities, even gain economic benefit (Livingstone, 2011). The most popular creative activities and creating something is creating music $34.2 \%$, followed by making artistic photographs of $27.6 \%$. Female adolescents prefer to make poetry or writing, while male adolescents prefer to make music (Hargittai \& Walejko, 2008).

Online opportunity and online risk are difficult to separate firmly because both are interrelated, and the link between risk and opportunity is often intertwined with subtle connections (Livingstone, 2013). This vague boundary as adolescents want to explore many things on the internet but unrealized the risk behind it. Often adolescents aim to gain new opportunity from the internet, but they are accidentally exposed to pornographic content or unknowingly they communicate with strangers. Therefore, online opportunity and online risk are closely related to adolescents' internet activities.

Internet activities can generally be distinguished by socioeconomic status(SES), 
gender \& age group, level of education, race and location (Green, Brady, Olafsson, Hartley, \& Lumby, 2011; Lee \& Kim, 2014; Livingstone et al., 2005; Vandoninck, d'Haenens, De Cock, \& Donoso, 2012). Likewise, sociodemographic factors also influence children and adolescents' media usage pattern (such as watching television, playing video games) (Hendriyani, Hollander, d'Haenens, \& Beentjes, 2011; Hendriyani, Hollander, Haenens, \& Beentjes, 2012).

Research conducted by Hendriyani et al., (2012) shows how gender and socioeconomic status influence relationships between children and the media. It turns out that gender can predict the availability of media types at home or in a child's room. The higher children socioeconomic status, the more and various types of media available in their home, easier and longer they access the internet or use other types of media (Hendriyani et al., 2012). Gender, age group, and socioeconomic status directly influence how long adolescents access the internet, also predict the type of website visited, the amount of adolescent interaction on the internet (Livingstone et al., 2005), the types of devices choices and where adolescents access the internet (Green et al., 2011).

Sociodemographic factors such as gender, parents' education level, parents' income and adolescents' age also influence motives of social media usage and the types of social media applications consumed (Vandoninck et al., 2012). Age, education level, frequency, and duration of internet usage are important predictors of surveillance motives. As for consumption motives, the dominant predictors are income, education level, and ease of access. However, social interaction motives turn out to be negatively predicted by age and level of education (Cho, de Zúñiga, Rojas, \& Shah, 2003).

The previous studies mentioned above were using sociodemographic factors as predictors of motives and media usage; and as a media usage differentiator. Compared to those studies, this study uses sociodemographic factors as a differentiator in the internet consequences i.e. online opportunities and online risk. In view of the fact that some adolescents might gain more benefits and opportunities than others and some might experience more risk and negative exposures. Therefore, the purpose of this study is to explore online opportunities and online risk of adolescents and to differentiate online opportunities and online risks based on gender, level of education, and school affiliation.

Based on the literature review, the research hypothesis as the following:

H1a: There is a significant difference in mean on the online opportunity, based on respondents' gender.

H1b: There is a significant difference in mean on the online risk, based on respondents' gender.

H2a: There is a significant difference in mean on the online opportunity, based on respondent's level of education

$\mathrm{H} 2 \mathrm{~b}$ : There is a significant difference in mean on online risk, based on respondents' level of education.

H3a: There is a significant difference in 
mean on online opportunity, based on respondents' school affiliation.

$\mathrm{H} 3 \mathrm{~b}$ : There is a significant difference in mean on online risk, based on respondents' school affiliation.

\section{Method of Research}

This research was using a crosssectional survey method. The survey was conducted in public and private junior high and senior high school students in DKI Jakarta, Indonesia. The sampling technique was multistage random sampling with the confidence level $95 \%$ and margin of error $4 \%$. The in-class survey was administered to 756 students from 23 schools in Jakarta. The research instrument was a self-administered questionnaire. The items of the questions were measured using a 5-point Likert scale ( $1=$ never; $5=$ always). In order to investigate the hypothesis, this research was carried out using an independent sample T-test analysis.

\section{Results and Discussion}

\section{Descriptive Findings}

Jakarta adolescents are very active internet users, they spend plenty time with the internet daily. Most adolescents (74.1\%) access the internet daily $(\mathrm{M}=4.615)$. On school days (Monday - Friday), they used the internet between 3 and 6 hours (47.9\%) and 27\% of teens stated using the Internet for 7 hours or more. Only $25.3 \%$ of them used the internet on school days 1-2 hours ( $M=2.648)$. Internet usage increased on holidays (Saturday, Sunday, national holidays and school holidays), 68.8\% of adolescents used the internet more than 5 hours per day ( $\mathrm{M}=3.385), 34.1 \%$ of $68.8 \%$ adolescents used the internet more than 9 hours per day. They also routinely involved the internet every day $(85.6 \% ; \mathrm{M}=3.726)$ and at the same time daily $(85.1 \% ; \mathrm{M}=3.496)$.

From the data above, it revealed that Jakarta adolescent's internet usage in terms of frequency, duration, and routine is high. Additionally, the amount of content accessed by adolescents and the number of applications used are also quite high. On average, they accessed 5-6 types of content $(\mathrm{M}=5.165)$ and used 10-11 applications $(\mathrm{M}=10.944)$. This high rate of access can be a reason for the high rate of frequency and duration. Adolescents may always be preoccupied with various content and applications via their smartphones because $87 \%$ of adolescents used the smartphone to access the internet. It can be concluded that adolescent's internet usage is relatively high in all aspects of frequency, duration, access, content, and routines. Whether this high internet usage provides significant online opportunities to adolescents or it generating online risks?

Descriptive findings on the online opportunity and online risk in the next table. In Table 1, online opportunity shows good results because $74.1 \%$ of adolescents benefit from the internet in the medium to high category $(\mathrm{M}=2.968)$. On the other hand, online risk experienced by $96 \%$ of adolescents is in a low category and those in the high category are only experienced by $1.1 \%$ of adolescents (M $=1.435$ ).

Adolescents obtained online opportunity in learning, creative participation, social participation, social relations, entertainment, commercial gains such as online 
Table 1. Online Opportunity and Online Risk

\begin{tabular}{lllll}
\hline \multicolumn{1}{c}{ Variable } & Category & Frequency & Percentage & Total \\
\hline \multirow{4}{*}{ Online Risk } & Low & 726 & $96 \%$ & $96 \%$ \\
& Medium & 22 & $2.9 \%$ & $2.9 \%$ \\
Total & High & 8 & $1.1 \%$ & $1.1 \%$ \\
Online & & 756 & $100 \%$ & $100 \%$ \\
Opportunity & & 196 & $25.9 \%$ & $25.9 \%$ \\
& & & & \\
& Medium & 495 & $65.5 \%$ & $65.5 \%$ \\
Total & High & 65 & $8.6 \%$ & $8.6 \%$ \\
\hline
\end{tabular}

Source: Results of statistical analysis from survey data by researcher, 2017

shopping, and personal benefits such as online courses. Social relation $(\mathrm{M}=3.906)$, entertainment $\quad(\mathrm{M}=3.821), \quad$ learning $(\mathrm{M}=3.787)$ are three dimensions that provide the highest benefits for adolescents. As many as $79.6 \%$ of adolescents "often" and "always" used social media; discussing and sharing information through instant messaging $75.5 \%$; seeking information for school needs $74.8 \%$; learning through the internet 67\%; watching short videos and music videos $69.5 \%$; and listening to music $67.8 \%$.

As for online risk, the type of online risk experienced by adolescents was the content risk, contact risk, and conduct risk. Sequentially from the highest to lowest risk are content risk $(\mathrm{M}=1.794)$, conduct risk $(\mathrm{M}=1.276)$, then contact risk $(\mathrm{M}=1.236)$. The content risk is the main risk experienced by adolescents especially violent content $(\mathrm{M}=2.337)$, hatred and racist content $(\mathrm{M}=2.245)$, and pornographic content $(\mathrm{M}=1.884)$. Parents and teachers should be aware of violent pornographic content such as rape and sexual abuse $(M=1.643)$ because the effect can very hazardous. For conduct risk, there were two dominant actions: sending messages or comments with harsh, invective, vulgar, and bad words ( $M=1.444)$; sending messages/photos/comments that insulting, degrading, humiliating ( $M=1,398)$. Although contact risk is at the lowest risk, the number of adolescents contacted people who fake their identity was quite alarming $(\mathrm{M}=1.544)$.

\section{Independent T-Test Analysis Findings}

Independent T-Test analysis conducted to find the differences between online opportunity and online risk based on adolescents' gender, based on adolescents' education level, and based on school affiliation (religious affiliated schools and public schools / non-religious affiliated school). The result can be seen in Table 2 and Table 3.

In overall result on online opportunity based on gender differences, female adolescents obtained more opportunities 
than male adolescents. T-test analysis shows there is no differences on online opportunity between female and male adolescents, then H1a hypothesis is rejected. Although there is no significant differences, when each dimension reviewed there are dimensions that show significant mean differences between male and female adolescents. Those dimensions are learning, social participation, social relations, commercial gain, and personal gain.

For online risk, result in table 3 shows that there is a significant difference in mean between male and female adolescents, then $\mathrm{H} 1 \mathrm{~b}$ hypothesis is accepted. Male adolescents experienced higher online risk significantly compare to female adolescents and this happened to all dimensions (content risk, contact risk, and conduct risk). This result shows that male adolescents more risky than female adolescents.

Next analysis shows there are significant differences on online opportunity and online risk based on adolescents' education level. Table 2 shows a significant difference on online opportunity at $\mathrm{p}<0.01$ between junior high school students and senior high school students. The significant difference in four dimensions, but only two dimensions that are not significantly different, i.e. social participation and creative participation. Overall, senior high school students benefit more online opportunities than junior high school students. There for, hypothesis $\mathrm{H} 2 \mathrm{a}$ is accepted, there is a significant difference in mean on online opportunity, based on adolescents' education level.

For online risk, the results in table
3 also show similar results with online opportunity, there is a significant difference on online risk at $\mathrm{p}<0.01$ between junior high school students and senior high school students. Thus, hypothesis H2b is accepted. From table 3 it can be seen that senior high school students experienced much higher online risk than junior high school students especially in content risk. Two other types of risk, contact risk and conduct risk, are not significantly different between junior high school students and senior high school students.

When schools are grouped according to their affiliates, i.e. religious affiliated schools and public schools (not affiliated with religion) it turns out that online opportunity and online risk do not show differences. For the results of online opportunity, table 2 shows that there is no difference in online opportunity obtained by adolescents in public schools with adolescents in religious affiliated schools. Based on these results: H3a hypothesis is rejected.

Even so, there are four dimensions of online opportunity that show differences: creative participation, social participation, social participation, and entertainment. Adolescents in public schools have higher mean scores on the dimensions of creative participation and social participation. Whereas adolescents in religious affiliated schools have higher mean scores on the dimensions of social relations and entertainment.

For online risk, the analysis also shows that there is no online risk difference between adolescents in public schools and 
adolescents in religious affiliated schools, $\mathrm{H} 3 \mathrm{~b}$ hypothesis is rejected. However, when examined per dimension, there are significant differences $(p<0.05)$ in content risk. Adolescents who attend religious schools have a higher mean score of content risk than adolescents who attend public schools. In general, the online risk mean score of adolescents who attend religious schools $(M=1.452)$ is higher than those who attend public schools $(\mathrm{M}=1.430)$. This needs to be observed by teachers and parents whose children attend religious affiliated schools, why this result could happen?

The internet usage of Jakarta adolescents is in the high category in terms of frequency, duration, and routine. In addition, the adolescents access the internet through private, mobile and easy-to-use devices, smartphones, which makes supervision more difficult. The escalating duration of internet usage during school holidays shows that teenagers do not do many activities with family or do activities other than surfing the internet. Parents should spend more time with teenagers or provide noninternet activities on weekends or holidays.

Teenagers experience more online opportunities than online risk in general. This is quite encouraging because teenagers get more benefits than the risks. The three dominant online opportunities are social relations, learning, and entertainment can be seen easily if we observe the adolescent's behavior when using the internet in their everyday lives, they often access Instagram and Youtube. Data from the APJII 2017 survey also shows high numbers for the social media usage in adolescents. In addition, there are obligations

Table 2. Online Opportunity Mean Score and Independent T-Test Coefficients

Based on Gender, Education Level, School Affiliation

\begin{tabular}{|c|c|c|c|c|c|c|c|c|c|c|c|c|}
\hline \multirow{3}{*}{ Dimensions } & \multicolumn{4}{|c|}{ Gender } & \multicolumn{4}{|c|}{ Education Level } & \multicolumn{4}{|c|}{ School Affiliation } \\
\hline & \multicolumn{2}{|c|}{ Mean } & \multicolumn{2}{|c|}{ T-test } & \multicolumn{2}{|c|}{ Mean } & \multicolumn{2}{|c|}{ T-test } & \multicolumn{2}{|c|}{ Mean } & \multicolumn{2}{|c|}{ T-test } \\
\hline & Female & Male & $\mathrm{t}$ & $\mathrm{p}$-value & $\begin{array}{l}\text { Middle } \\
\text { school }\end{array}$ & $\begin{array}{l}\text { High } \\
\text { School }\end{array}$ & $\mathrm{t}$ & $\mathrm{p}$-value & $\begin{array}{l}\text { Religion } \\
\text { School }\end{array}$ & $\begin{array}{l}\text { Public } \\
\text { School }\end{array}$ & $\mathrm{t}$ & $\mathrm{p}$-value \\
\hline Learning & 3,852 & 3,713 & $2,538 *$ & 0.012 & 3,650 & 3,948 & $-5,508 * *$ & 0,000 & 3.8048 & 3.7814 & 0.357 & 0.721 \\
\hline $\begin{array}{l}\text { Creative } \\
\text { Participation } \\
\text { Creativeicipation }\end{array}$ & 2,086 & 2,083 & 0.031 & 0.975 & 2,144 & 2014 & 1,651 & 0.099 & 1.9420 & 2.1296 & $-2,035 *$ & 0.043 \\
\hline $\begin{array}{l}\text { Sosial } \\
\text { Participation }\end{array}$ & 2,515 & 3,045 & $-5,734 * *$ & 0,000 & 2,757 & 2,771 & -0.149 & 0.882 & 2.5912 & 2.8174 & $-2,079 *$ & 0.038 \\
\hline $\begin{array}{l}\text { Sosial } \\
\text { Relation }\end{array}$ & 4,047 & 3,745 & $5,136^{* *}$ & 0,000 & 3,786 & 4,047 & $-4,471 * *$ & 0,000 & 4,0387 & 3.8638 & $2,597 *$ & 0.010 \\
\hline Entertainment & 3,864 & 3,773 & 1,348 & 0.178 & 3,716 & 3,946 & $-3,431 * *$ & 0.001 & 3.9613 & 3.7774 & $2,374 *$ & 0.018 \\
\hline $\begin{array}{l}\text { Commercial } \\
\text { Gain }\end{array}$ & 2,065 & 3,773 & $2,087 *$ & 0.037 & 1,888 & 2,119 & $-3,193 * *$ & 0.001 & 1.9890 & 1.9965 & -0.087 & 0.930 \\
\hline Personal Gain & 2,478 & 2,350 & $1,991 *$ & 0.047 & 2,267 & 2,595 & $-5,187 * *$ & 0,000 & 2.4779 & 2.3991 & 1,063 & 0.289 \\
\hline $\begin{array}{l}\text { Variable } \\
\text { Online } \\
\text { Opportunity }\end{array}$ & 2,986 & 2,946 & 0.946 & 0.345 & 2,887 & 3,063 & $-4,223 * *$ & 0,000 & 2.9721 & 2.9665 & 0.115 & 0.908 \\
\hline
\end{tabular}

Remarks: ** significant at $\mathrm{p}<0.01$; ${ }^{*}$ significant at $\mathrm{p}<0.05$;

Source: Results of statistical analysis from survey data by researcher, 2017 
Table 3. Online Risk Mean Score and Independent T-Test Coefficients Based on Gender, Education Level, School Affiliation

\begin{tabular}{|c|c|c|c|c|c|c|c|c|c|c|c|c|}
\hline \multirow{3}{*}{ Dimensions } & \multicolumn{4}{|c|}{ Gender } & \multicolumn{4}{|c|}{ Education Level } & \multicolumn{4}{|c|}{ School Affiliation } \\
\hline & \multicolumn{2}{|c|}{ Mean } & \multicolumn{2}{|c|}{ T-test } & \multicolumn{2}{|c|}{ Mean } & \multicolumn{2}{|c|}{ T-test } & \multicolumn{2}{|c|}{ Mean } & \multicolumn{2}{|c|}{ T-test } \\
\hline & Female & Male & $\mathrm{t}$ & $\mathrm{p}$-value & $\begin{array}{l}\text { Middle } \\
\text { school }\end{array}$ & $\begin{array}{l}\text { High } \\
\text { School }\end{array}$ & $\mathrm{t}$ & p-value & $\begin{array}{l}\text { Religion } \\
\text { School }\end{array}$ & $\begin{array}{l}\text { Public } \\
\text { School }\end{array}$ & $\mathrm{t}$ & p-value \\
\hline Content risk & 1,706 & 1,894 & $-4,025 * *$ & 0,000 & 1,660 & 1,952 & $-6,253 * *$ & 0,000 & 1.8923 & 1.7631 & $2,306^{*}$ & 0.022 \\
\hline $\begin{array}{l}\text { Contact risk } \\
\text { Creativeicipation }\end{array}$ & 1,177 & 1,302 & $-3,172 * *$ & 0.002 & 1,227 & 1,246 & -0.486 & 0.627 & 1.2099 & 1.2438 & -0.855 & 0.393 \\
\hline Conduct risk & 1,218 & 1,343 & $-3,531 * *$ & 0,000 & 1,251 & 1,306 & $-1,515$ & 0.130 & 1.2530 & 1.2840 & -0.883 & 0.378 \\
\hline $\begin{array}{l}\text { Variable } \\
\text { Online Risk }\end{array}$ & 1,367 & 1,513 & $-4,222 * *$ & 0,000 & 1,379 & 1,501 & $-3,467 * *$ & 0.130 & 1.4517 & 1.4303 & 0.93 & 0.554 \\
\hline
\end{tabular}

Remarks: ${ }^{\star \star}$ significant at $\mathrm{p}<0.01 ;{ }^{\star}$ significant at $\mathrm{p}<0.05$;

Source: Results of statistical analysis from survey data by researcher, 2017

and demands from schools to use the internet as part of the teaching and learning process. The high need for entertainment can be seen from the high access to Youtube to view short videos and music videos.

Compare to other countries such as countries in Europe, using the internet to socialize, getting entertainment, in general, is also done by teenagers in Europe. But in all European countries, children and adolescents prioritize the use of the internet for communication and social relations; for entertainment and play; and attain information (Hasebrink, Livingstone, Haddon, \& Olafsson, 2009; Livingstone, 2011).

The results of online risk, sequences from the highest to the lowest are: content risk, action risk, contact risk; these results are similar to the results of research by Livingstone, Kirwil, Ponte, \& Staksrud in adolescents in Europe (Livingstone, Kirwil, Ponte, \& Staksrud, 2014). In addition, it turns out the risk of aggressiveness and sexual risk dominates adolescents. Then, the content risk that must be watched is all content that contains violence, including physical violence such as assault and murder, as well as violence in the form of verbal expressions of hatred, insults and harsh words / dirty words.

The results of the independent T-test analysis are three hypotheses accepted and three hypotheses rejected. The important result that must be considered that the level of adolescent education is a vital differentiating factor for the online opportunity and online risk. The higher the level of education of adolescents, the higher they will benefit from the internet as well as the riskier. It is presumed that the higher the level of adolescent education, the more skilled they are to use the internet, the more skilled they are at risky behaviors.

The level of education is an important differentiator for online opportunity and online risk. These results can be explained from previous research which states that sociodemographic status affects adolescents on internet activities. The higher the level of education of adolescents, the older, the richer and the higher the level of education of their parents, the more active adolescents using 
the internet (Luthfia, 2018) which they have the potential to gain more opportunity and experience higher risk than adolescents with lower levels of education.

Another interesting result, there is a significant difference in mean score between male and female adolescents on online risk. Male and female adolescents experience significant online risk differences in all dimensions - dimensions of content risk, contact risk, and conduct risk. So, male adolescents are far more at risk than female adolescents. This result is in line with the results of Notten \& Nikken study which states that teen girls are significantly less involved in risky behavior on the internet (Notten \& Nikken, 2014). Parents and teachers must be more vigilant, more attentive, and more intense in accompanying male adolescents so that they can benefit more from the internet and be able to avoid online risk.

For online opportunity, there is no difference between male and female adolescents. However, there are prominent differences between male and female, especially in the dimensions of social participation and social relations. Male adolescents have significantly higher mean score in the social participation because male adolescents are more active in joining online communities and they are more active in participating in online groups/forums. While female adolescents have significant high mean scores on the social relations dimension because they are more active in discussing through instant messaging, using social media, and doing group assignments through the internet.
Another thing that is noteworthy is the result of school affiliation. Although it is not significantly different, it turns out that the content risk of religious affiliated schools is higher than public schools. This can be explained through the results of online opportunities in religious affiliated schools. It is seen that teenagers in religious affiliated schools use the internet more for entertainment and social relations, where they are more intensely accessing Youtube, online games and social media. It could be that the online risk they experience comes from this type of utilization, because online opportunity affects the occurrence of online risk. The higher the online opportunity that teenagers get, then they have the potential to experience higher online risk (Luthfia, 2018).

\section{Conclusion}

Indonesian adolescents represented by Jakarta adolescents are very active internet users with a high duration, frequency and routine through the usage of smartphones. Adolescents get higher online opportunity than online risk. Even so, parents, teachers, and the social environment must still be aware of online risk experienced by adolescents because online risk is dominated by violent, pornographic, violent pornography, hate speech \& SARA content, as well as contact with strangers.

Sociodemographic factors have proven to play a role in the online opportunity and online risk when adolescents use the internet. The level of education is the most important factor that distinguishes online opportunity and online risk. This means that the higher the level of adolescent education, they will get more opportunities as well as potentially experience 
a higher risk. Gender is also an important differentiating factor, especially on online risk because male adolescents are significantly more at risk than female adolescents.

This study has limitations, only one social aspect has been studied, sociodemographic. Suggestions for further research are examining the influence of social and psychological factors on online opportunity and online risk, how the role of the social environment of adolescents to reduce online risk and examine the influence of digital knowledge and skills to online opportunity.

\section{Acknowledgment}

This work is supported by Directorate General of Strengthening for Research and Development, Ministry of Research, Technology, and Higher Education, Republic of Indonesia, with contract number 0422/ K3/KM/2017.

\section{References}

Asosiasi Penyelenggara Jasa Internet Indonesia - APJII. (2017). Penetrasi \& Perilaku Pengguna Internet Indonesia Survey 2017.

Baek, Y. M., Cho, Y., \& Kim, H. (2014). Attachment Style and its Influence on the Activities, Motives, and Consequences of SNS Use. Journal of Broadcasting \& Electronic Media, 58(4), 37-41. https:// doi.org/10.1080/08838151.2014.966362

Borah, P. (2017). Emerging communication technology research: Theoretical and methodological variables in the last 16 years and future directions. New Media \& Society, 19(4), 616-636. https:// doi.org/10.1177/1461444815621512

Chin Hooi, P. S. (2011). Influence of parents and peers on Internet usage and addiction amongst school-going youths in Malaysia. ProQuest Dissertations and Theses, (January), 238-n/a.

Cho, J., de Zúñiga, H. G., Rojas, H., \& Shah, D. V. (2003). Beyond access: The digital divide and Internet uses and gratifications. IT \& Society, 1(4), 46-72.

Green, L., Brady, D., Olafsson, K., Hartley, J., \& Lumby, C. (2011). Risks and safety for Australian children on the internet. Cultural Science, 4(1), 75.

Hargittai, E., \& Walejko, G. (2008). THE PARTICIPATION DIVIDE : Content creation and sharing in the digital age. Information, Communication \& Society, 11(2), 239-256.

Hasebrink, U., Livingstone, S., Haddon, L., \& Olafsson, K. (2009). Comparing children's online opportunities and risks across Europe: Cross-national comparisons for EU Kids Online.

Hendriyani, Hollander, E., d'Haenens, L., \& Beentjes, J. (2011). Children's Television in Indonesia. Journal of Children and Media, 5(1), 86-101. https://doi.org/10. 1080/17482798.2011.535404

Hendriyani, Hollander, E., Haenens, L., \& Beentjes, J. W. J. (2012). Children's media use in Indonesia. Asian Journal of Communication, 22(3), 304-319.

Ito, M. (2007). Technologies of the Childhood Imagination: Media Mixes, Hypersociality and Recombinant Cultural Form. Structures of Participation in Digital Culture, 4, 31-34.

Ito, M., Baumer, S., Bittanti, M., Cody, R., Stephenson, B., Horst, H., ... Perkel, D. (2009). Hanging Out, Messing Around, and Geeking Out. Kids Living and Learning with New Media. MIT Press.

Jenkins, H. (2006). Confronting the Challenges of Participatoty Culture: Media Education for 21st Century. 
Kompas, H. (2018a, July). "Candu Gawai" nan Membius. Harian Kompas, 23 Juli 2018, p. 2.

Kompas, H. (2018b, July). Kecanduan Gawai Ancam Anak-anak. Harian Kompas, 23 Juli 2018, p. 2.

Lee, J. H., \& Kim, J. (2014). Sociodemographic gaps in mobile use, causes, and consequences: a multi-group analysis of the mobile divide model. Information, Communication \& Society, 17(8), 917-936. https://doi.org/10.1080/ 1369118X.2013.860182

Leung, L. (2008). Linking Psychological Attributes ToAddiction and Improper Use of the Mobile Phone Among Adolescents in Hong Kong. Journal of Children and Media, 2(2), 93-113. https://doi. org/10.1080/17482790802078565

Leung, L. (2014). Predicting Internet risks : a longitudinal panel study of gratificationssought, Internet addiction symptoms , and social media use among children and adolescents. Health Psychology \& Behavioural Medicine, 2(1), 424-439. https://doi.org/10.1080/21642850.2014. 902316

Livingstone, S., Kirwil, L., Ponte, C., \& Staksrud, E. (2014). In their own words: What bothers children online? European Journal of Communication, 29(3), 271-288. https://doi. org/10.1177/0267323114521045

Livingstone, Sonia. (2008). Taking risky opportunities in youthful content creation: teenagers' use of social networking sites for intimacy, privacy and self-expression. https://doi. org/10.1177/1461444808089415

Livingstone, Sonia. (2011). Internet, Children, and Youth. In The Handbook of Internet Studies (pp. 348-368). https://doi. org/10.1002/9781444314861.ch16
Livingstone, Sonia. (2013). Online risk , harm and vulnerability: Reflections on the evidence base for child Internet safety policy. ZER: Journal of Communication Studies, 18(35), 13-28.

Livingstone, Sonia, Bober, M., \& Helsper, E. J. (2005). Active participation or just more information? Young people's take-up of opportunities to act and interact on the Internet. Information, Communication \& Society, 8(3), 287-314.

Livingstone, Sonia, \& Haddon, L. (2014). Theoretical framework for children ' $S$ internet use. In Sonia Livingstone, $H$. Leslie, \& A. Gorzig (Eds.), Children, Risk and Safety on the Internet: Research and Policy Challenges in Comparative Perspective (pp. 1-14). Bristol: The Policy Press.

Livingstone, Sonia, \& Helsper, E. (2010). Balancing opportunities and risks in teenagers' use of the internet: the role of online skills and internet self-efficacy. https://doi. org/10.1177/1461444809342697

Livingstone, Sonia, Mascheroni, G., \& Staksrud, E. (2015). Developing a framework for researching children' $s$ online risks and opportunities in Europe.

Luthfia, A. (2018). Online Opportunity dan Reduksi Online Risk Melalui Lingkungan Sosial Remaja (Survei pada Siswa SMP dan SMA di DKI Jakarta). University of Indonesia.

Michelle, M., \& Ramadan, R. (2018). Fakta Foto Bugil Remaja: Dianggap Tanda Sayang, jadi Mantan Foto Disebar. Retrieved March 7, 2018, from HAIOnline.com website: http://hai.grid.id/ Self-Improvement/Psycho/Fakta-FotoBugil-Remaja-Dianggap-Tanda-SayangJadi-Mantan-Foto-Disebar 
Notten, N., \& Nikken, P. (2014). Boys and girls taking risks online: A gendered perspective on social context and adolescents' risky online behavior. New Media \& Society, 1-24. https://doi. org/10.1177/1461444814552379

Quan-Hasse, A., \& Young, A. L. (2014). The Uses and Gratifications (U\&G) Approach as a Lens for Studying Social Media Practice. In R. S. Fortner \& P. M. Fackler (Eds.), The Handbook of Media and Mass Communication Theory Volume 1 (pp. 269-286). West Sussex, UK: John Wiley \& Sons, Inc.

Rice, R. E. (2017). Intermediality and the Diffusion of Innovations. Human Communication Research, 43(4), 531544. https://doi.org/10.1111/hcre.12119

Ruggiero, T. E. (2016). Uses and Gratifications Theory in the 21st Century. In R. Wei (Ed.), Refining Milestone Mass Communications Theories for the 21st Century (pp. 36-70). Oxon, UK: Routledge.
Staksrud, E., \& Livingstone, S. (2009). Children and online risk: powerless victims or resourceful participants? Information, Communication \& Society, 12(3), 364-387. https://doi. org/10.1080/13691180802635455

Steiner-Adair, C., \& Barker, T. H. (2013). The Big Disconnect. Protecting Childhood and Family Relationship in the Digital Age. New York: Harper Collins.

Sundar, S. S., \& Limperos, A. M. (2013). Uses and Grats 2 . 0 : New Gratifications for New Media. Journal of Broadcasting \& Electronic Media, 57(4), 504-525. https://doi.org/10.1080/08838151.2013. 845827

Vandoninck, S., d'Haenens, L., De Cock, R., \& Donoso, V. (2012). Social networking sites and contact risks among Flemish youth. Childhood, 19(1), 69-85. https:// doi.org/10.1177/0907568211406456 